\title{
Effects of N-Methyl Peptide Bonds on Peptide Utilization by Escherichia coli
}

\author{
By J. W. PAYNE \\ Microbiological Research Establishment, Porton, Salisbury, Wiltshire
}

(Accepted for publication 27 January 1972)

\begin{abstract}
SUMMARY
Glycine homopeptides are concentrated by Escherichia coli and are completely hydrolysed by intracellular peptidases. Glycine peptides in which a peptide-bond nitrogen is methylated, i.e. glycylsarcosine and glycylglycylsarcosine, still use the peptide transport systems, but the substituted peptide bonds are not hydrolysed. Glycylsarcosine is thus nutritionally inactive, but it competes with other dipeptides for uptake. Only the N-terminal residue of glycylglycylsarcosine is utilized by a glycine auxotroph. The results reflect the different specificities of the peptide transport systems and the intracellular peptidases of $E$. coli.
\end{abstract}

\section{INTRODUCTION}

Escherichia coli concentrates dipeptides and oligopeptides by separate transport systems (Payne, 1968; Payne \& Gilvarg, 197I). The main specificities of these systems, with respect to peptide structure, are as follows: (i) the nature of the amino acid side-chain substituents is unimportant (Payne, I968; Payne \& Gilvarg, I97I); (ii) only dipeptide uptake requires an unsubstituted C-terminal carboxyl group (Payne \& Gilvarg, I968a); (iii) a peptide must carry a protonated N-terminal $\alpha$-amino group (Gilvarg \& Katchalski, I965; Payne, I97I $a$, b). Escherichia coli also has many intracellular peptidases to cleave most peptides taken up from its environment to the level of their nutritionally active amino acid components. This paper describes studies on the utilization of peptides carrying internal N-methyl groups, the results of which contribute to an understanding of the specificities, with respect to the substitution of the peptide bond, of the transport systems and of the intracellular peptidases. A preliminary report on certain aspects of these studies has been published (Payne, 1972 a).

\section{METHODS}

Micro-organisms. Escherichia coli $\mathrm{w}$, strain $\mathrm{M}-\mathrm{I} 23, \mathrm{gly}^{-} / \mathrm{ser}^{-}$, and the oligopeptide transport deficient mutant M-I23.TOR (Payne, 1968) were grown in the minimal medium A of Davis \& Mingioli (1950) supplemented with $0.5 \%$ glucose and I mM-glycine. Escherichia coli KI 2, strain ASor 3, a lysine auxotroph derived from strain $200 \mathrm{IC}^{\mathrm{C}} \mathrm{F}^{-}$, $\mathrm{Thr}^{-}$, $\mathrm{Leu}^{-}$, thiamin-, was grown in minimal medium M56 (Weismeyer \& Cohn, I960), supplemented with $0.5 \%$ glucose; the required amino acids were supplied at $50 \mathrm{mg} / \mathrm{l}$ and thiamin at $5 \mathrm{mg} / \mathrm{l}$. Cultures $(10 \mathrm{ml})$ were inoculated with about 2 to $5 \times 10^{7}$ organisms taken from an exponential phase culture and were grown in $20 \mathrm{~mm}$ diameter tubes shaking at $37^{\circ} \mathrm{C}$; growth curves were obtained from $E_{560}$ measurements in a Bausch and Lomb Spectronic 20.

Peptidase assays were performed using the $\mathrm{Cu}^{2+}+$ trinitrobenzene sulphonate (TNBS) procedure of Binkley, Leibach \& King (1968), described elsewhere (Payne, 1972b). In 
general, exponential-phase organisms were collected by centrifugation, washed once with distilled water, and resuspended in water to about $2.5 \times 10^{9}$ organisms $/ \mathrm{ml}$. Toluene ( $\left.0 \cdot 1 \mathrm{ml}\right)$ was added to $2.5 \mathrm{ml}$ of this suspension, which was mixed on a vortex mixer for three min; the suspension was then equilibrated at $37^{\circ} \mathrm{C}$ for $20 \mathrm{~min}$ with frequent shaking. A standard

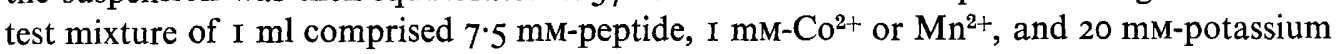
phosphate buffer, $\mathrm{pH} 7 \cdot 8$. equilibrated at $37^{\circ} \mathrm{C}$. The reaction was started by the addition of $0.2 \mathrm{ml}$ of toluene-treated bacterial suspension and incubation was continued. Samples (O. I ml) were removed periodically for assay by the procedure described elsewhere (Payne, 1972 b). Samples were also removed for electrophoretic studies.

The presence of $\mathrm{Cu}^{2+}$ in the reagent generally prevents reaction of the TNBS with peptides and yields coloured reaction products specifically with amino acids. However, glycylsarcosine gave a full colour response. This anomaly, and the fact that sarcosine (with a secondary amino group) gives no colour response, prevented application of the assay to glycylsarcosine cleavage, but did not prevent the procedure being used for assay of the competitive effects of glycylsarcosine.

Electrophoresis. Samples (0.0 $\mathrm{m} \mathrm{m}$ ) for electrophoresis were removed from $\mathrm{I} \mathrm{ml}$ incubation mixtures containing $7.5 \mathrm{~mm}$-peptide, I mM- $\mathrm{Co}^{2+}, 20 \mathrm{~mm}$-potassium phosphate buffer, $\mathrm{pH} 7 \cdot 8$, and toluene-treated bacterial suspension, after incubation for $2 \mathrm{~h}$ at $37^{\circ} \mathrm{C}$. Samples were run on a Shandon flat plate apparatus using Whatman no. I paper for $70 \mathrm{~min}, 56 \mathrm{volts} / \mathrm{cm}$ at $\mathrm{pH} 2 \cdot \mathrm{I}$ in acetic acid $(8 \%, \mathrm{v} / \mathrm{v})$ and formic acid $(2 \%, \mathrm{v} / \mathrm{v})$. Electrophoretograms were developed with cadmium-ninhydrin reagent (Heilmann, Barrolier \& Watzke, I957). This reagent gave the following colours with the different peptides and amino acids which allowed unambiguous identification when relative mobilities were similar. Sarcosine and glycine stained red; diglycine, triglycine, glycylsarcosine and glycylglycylsarcosine all stained yellow changing to orange.

\section{RESULTS}

\section{Utilization of dipeptides}

Dipeptides with acyl substituted $\mathrm{N}$-terminal $\alpha$-amino groups cannot be utilized by Escherichia coli (Gilvarg \& Katchalski, I965; Payne, I97la), whereas dipeptides with methylated $\mathrm{N}$-terminal $\alpha$-amino groups, e.g. sarcosylglycine, sarcosylserine are concentrated via the peptide transport system, and following cleavage by intracellular peptidases are used nutritionally. Fig. I shows that glycylsarcosine, a dipeptide with an internal N-methylated peptide bond, was unable to support growth of M-I23 at any concentration tested (0.5 to IO $\mathrm{mM}$ ), while the structurally related dipeptides, glycylproline (I mM) (not shown) and glycylglycine (I mM), both acted as sources of the required amino acid and supported exponential growth of M-I23. Glycylsarcosine did not inhibit the growth either of M-I 23 on media supplemented with glycine or of the wild-type strain, but failed to support growth because it was not hydrolysed, as shown by investigation of toluene-treated bacteria. The assay described previously (Payne, $1972 \mathrm{~b}$ ) could readily be used to demonstrate cleavage of glycylglycine (Table I). For the reasons given in Methods, this assay is not applicable to glycylsarcosine, but electrophoretic examination of an incubation mixture containing glycylsarcosine showed the peptide to be unhydrolysed under conditions that produced complete hydrolysis of glycylglycine and glycylproline (see Methods). The result shows the strict specificity of the intracellular dipeptidases, aminopeptidases and carboxypeptidases of Escherichia coli for non-substitution of the peptide bond in a dipeptide, and further shows that the ability of certain of these peptidases to cleave imino-peptide bonds (e.g. in glycylproline) does not extend to $\mathrm{N}$-methyl peptide bonds. 


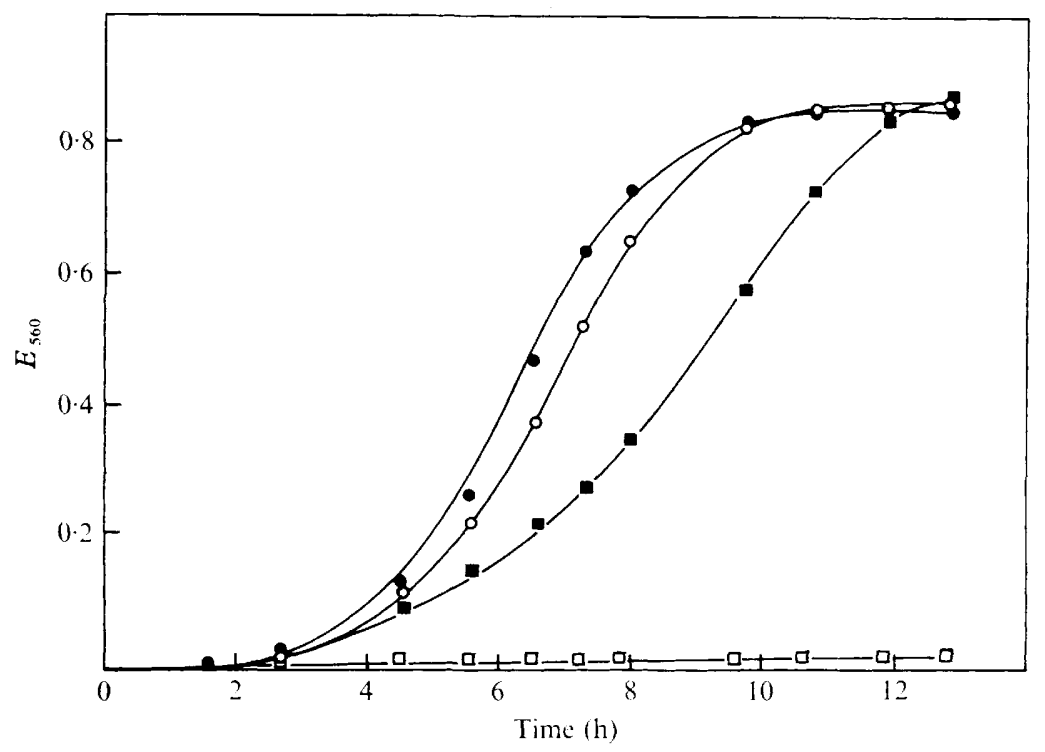

Fig. I. The effect of glycylsarcosine on the utilization of diglycine by the Escherichia coli auxotroph M-I 23. O, + I mM-diglycine; $O$, + I mM-diglycine + I.3 mM-glycylsarcosine; $\mathbf{0},+\mathrm{I}$ mM-diglycine +8 mm-glycylsarcosine; $\square$, unsupplemented media, or glycylsarcosine alone ( 0.5 to $10 \mathrm{~mm}$ ).

Table I. Hydrolysis of glycyl peptides by toluene treated Escherichia coli

Peptidase assays were performed as described in Methods. The concentration of each peptide was $7.5 \mathrm{~mm}$, and that of each cation was I mM. Activities are expressed as $\mu$ mol glycine released/ $\mathrm{min} / \mathrm{ml}$ bacterial suspension.

\section{Peptide}

Gly-gly
Gly-gly
Gly-gly
Gly-gly
Gly-gly+ Gly-sarc
Gly-gly-gly
Gly-gly-gly
Gly-gly-gly
Gly-gly-sarc
Gly-gly-sarc
Gly-gly-sarc

Supplement
None
$\mathrm{Co}^{2+}$
$\mathrm{Mn}^{2+}$
$\mathrm{Co}^{2+}+\mathrm{Zn}^{2}$
$\mathrm{Co}^{2+}$
$\mathrm{None}^{2}$
$\mathrm{Co}^{2+}$
$\mathrm{Mn}^{2+}$
$\mathrm{None}^{2+}$
$\mathrm{Co}^{2+}$
$\mathrm{Mn}^{2+}$

Activity $\left(\times 10^{3}\right)$
5
100
16
9
100
5
61
35
4
14
6

The absence of peptidase activity able to cleave glycylsarcosine is sufficient to explain the observed lack of growth of the glycine auxotroph. To decide if glycylsarcosine can use the dipeptide transport system, the ability of glycylsarcosine to inhibit the uptake of other dipeptides using the system was indirectly assessed. The growth of the glycine auxotroph on diglycine was inhibited by glycylsarcosine (Fig. I); glycylsarcosine also inhibited the growth on glycylproline (not shown). This effect was specific for dipeptides, for similar concentrations of glycylsarcosine did not inhibit growth of M-I23 on triglycine or on glycine, or growth of the wild-type strain. The observed inhibition of growth could arise from interference with either dipeptide uptake or dipeptide cleavage. The former seems more likely because in a peptidase assay using toluene-treated organisms, glycylsarcosine $(7.5 \mathrm{~mm})$ did not inhibit the cleavage of diglycine $(7.5 \mathrm{~mm})$ (Table I). A similar test made use of the fact that valine is inhibitory to Escherichia coli $\mathrm{K}$ I 2 (Leavitt \& Umbarger, 1962). Glycylvaline is therefore also potentially 


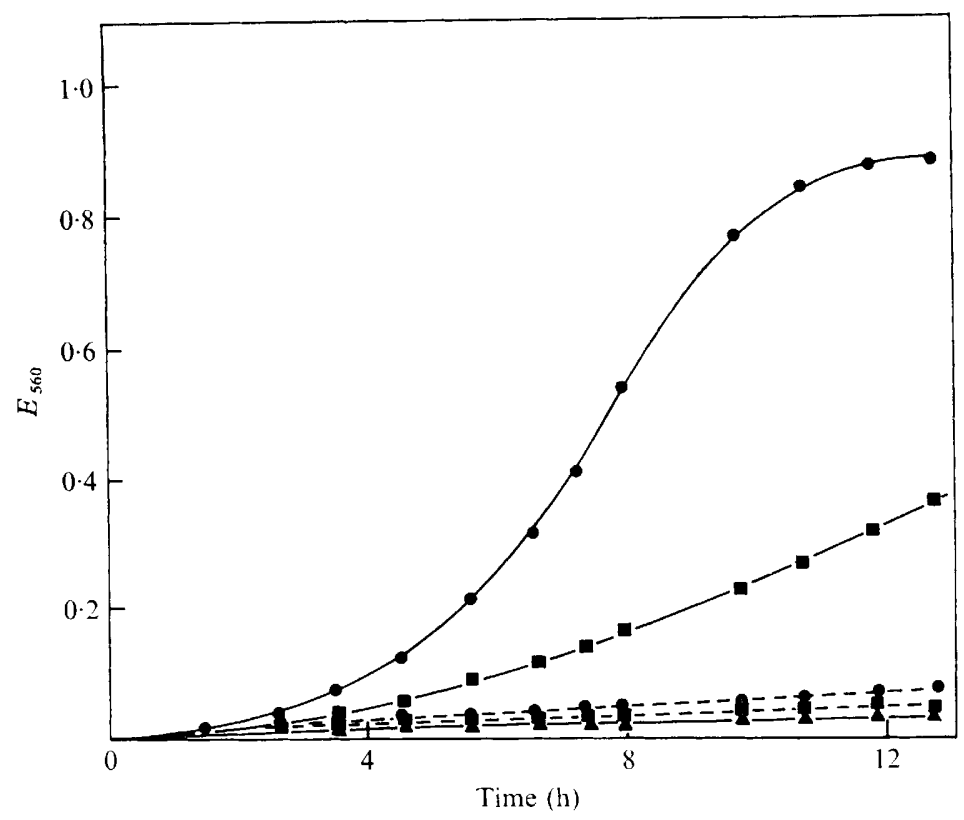

Fig. 2. Utilization of triglycine and glycylglycylsarcosine by the Escherichia coli glycine auxotrophs $\mathrm{M}-\mathrm{I} 23$ and $\mathrm{M}$-I 23 . TOR.,$+0.625 \mathrm{mM}$-triglycine; $\boldsymbol{\nabla},+3 \mathrm{~mm}$-glycylglycylsarcosine; $\boldsymbol{\Delta}$, unsupplemented media; --, M-I 23; --.-, M-I 23.TOR.

inhibitory but its inhibition can be overcome if it can be prevented either from entering the organism, or being broken down to give valine, or both (Payne, I97I $a$ ). In such a test, glycylglycine (Io mM), glycylsarcosine and glycylproline were all to varying extents able to overcome the inhibition caused by glycylvaline $(0.4 \mathrm{~mm})$. These results suggest that the dipeptide transport system is able to handle dipeptides in which the peptide bond is methylated. This conclusion accords with the observed ability to handle glycylproline, in which the imino-nitrogen also lacks a hydrogen atom. With glycylsarcosine the transport capability and peptidase activity of the organism do not parallel one another; the result supports earlier reports (Kessel \& Lubin, 1963) that peptides may be accumulated in the absence of the corresponding peptidase activity, thereby indicating that peptide transport and peptidase activity are not coupled in an obligatory manner (Sussman \& Gilvarg, 1970).

\section{Utilization of oligopeptides}

Growth studies using an oligopeptide carrying an internal N-methyl group, glycylglycylsarcosine, showed that it could act as a source of glycine for M-I23 (Fig. 2), so Escherichia coli can both take up and cleave the tripeptide. However, exponential growth was not achieved with 0.5 to 3.0 mm-tripeptide; a slow growth rate, varying with the concentration of the tripeptide was observed. The final growth yield on glycylglycylsarcosine was compatible with the utilization of only one glycine residue. Electrophoretic analysis of the products obtained by incubating the tripeptide with toluene-treated bacteria showed glycine and glycylsarcosine as the final digestion products. This limited cleavage reflects the lack of specificity of the relevant peptidase activities with respect to the methylation of the peptide bond contiguous to that cleaved; it also indicates that the bacterial carboxypeptidases display strict specificity for an unsubstituted C-terminal peptide bond; and it substantiates 


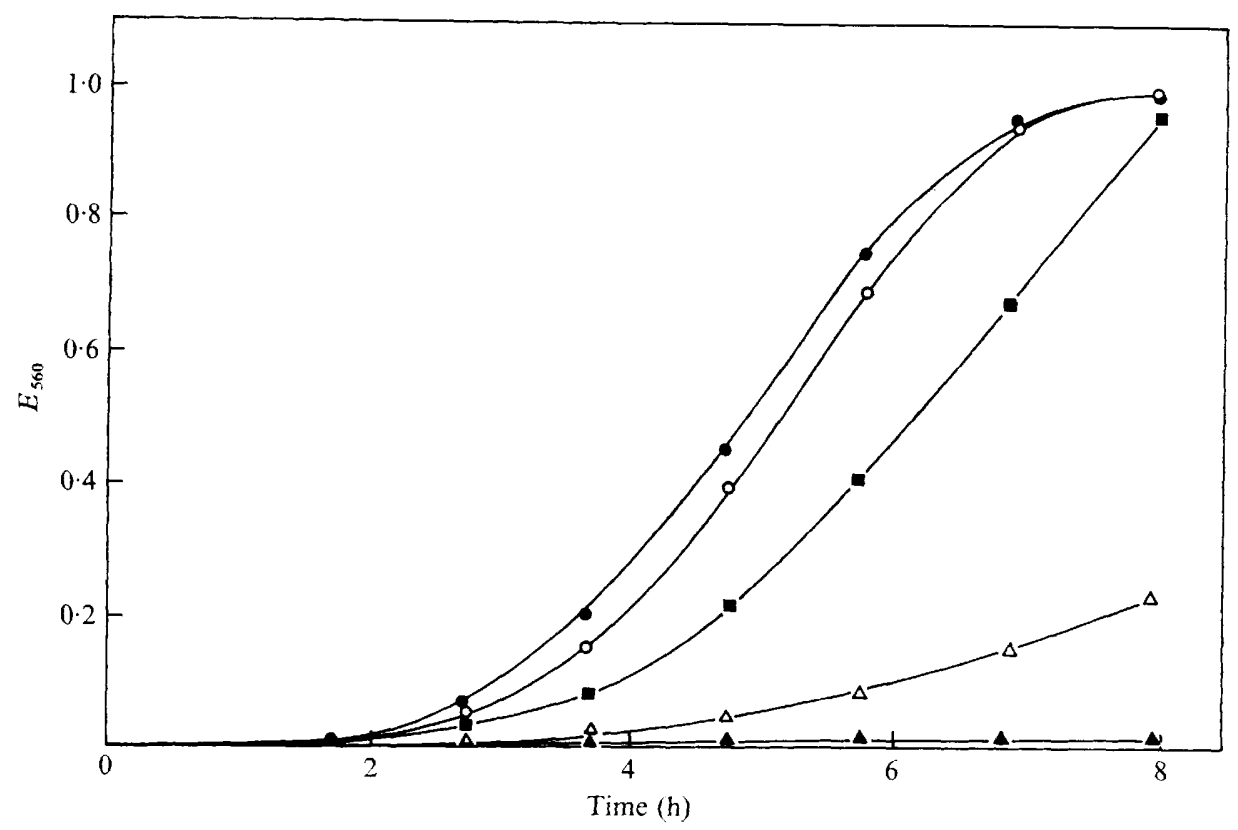

Fig. 3. Relative abilities of triglycine and glycylglycylsarcosine to relieve triornithine inhibition of wild-type Escherichia coli $\mathrm{w}$. Except as indicated, $0.04 \mathrm{~mm}$-triornithine was always present. 0 , Triornithine omitted; $O,+0.125 \mathrm{~mm}$-triglycine; $\boldsymbol{\square},+0.625 \mathrm{~mm}$-glycylglycylsarcosine; $\triangle,+0.125 \mathrm{~mm}$ glycylglycylsarcosine; $\boldsymbol{\Lambda}$, triornithine alone.

the strict requirement of the dipeptidases for an unsubstituted peptide bond, indicated previously by the studies with glycylsarcosine.

The role of the oligopeptide transport system in tripeptide uptake was studied using a mutant of the glycine auxotroph that is defective in oligopeptide transport, but retains normal oligopeptidase activity (Payne, 1968; Gilvarg \& Levin, I97I). This mutant could not use glycine oligopeptides (Fig. 2), although the growth response to glycine itself and to glycine dipeptides was identical to that seen with the original strain (Payne, I968). Glycylglycylsarcosine did not support growth of this mutant (Fig. 2) which suggests that glycylglycylsarcosine, like other glycine oligopeptides, enters the original strain by the oligopeptide transport system that is absent in the mutant. This result may be contrasted with an unpublished observation that glutathione, which also supports slow growth of the glycine auxotroph, does so equally in the original strain and the transport mutant, suggesting that this $\gamma$-linked tripeptide does not use the oligopeptide transport system.

To further test the affinity of glycylglycylsarcosine for the transport system its ability to compete for uptake with other oligopeptides was studied. Glycylglycylsarcosine and triglycine were both effective in reversing the bactericidal effect of triornithine (Fig. 3); as the toxic effect of triornithine is a property of the peptide itself, and its degradation products are not inhibitory (Gilvarg \& Levin, I97I), this relief of inhibition may be attributed to the glycyl-peptide competitors interfering with triornithine uptake and thereby preventing it from reaching an inhibitory internal concentration. The result confirms that glycylglycylsarcosine can use the oligopeptide transport system, indicating that the system can tolerate substitution of the second peptide bond.

The growth-limiting step responsible for the slow growth on glycylglycylsarcosine is not known, and it may be a low rate of uptake or cleavage or both. The triornithine competition 
studies indicate that triglycine is a more efficient competitor than glycylglycylsarcosine suggesting that the latter may have a lower affinity for the transport system. Measurements of peptidase activity show that the rate of glycine release from glycylglycylsarcosine is also considerably slower than from triglycine (Table I).

\section{DISCUSSION}

The ability of Escherichia coli transport systems to accept peptides with N-methylated peptide bonds seems to confer little nutritional advantage, because the organism lacks enzymes able to cleave substituted peptide bonds, and, in its natural habitat in the gut, it presumably encounters predominantly protein degradation products in which the peptide bonds are unsubstituted. However, this ability may be of some relevance to antibiotic sensitivity, for peptide antibiotics are frequently distinguished from other natural peptides by their complement of N-methyl amino acids (Bodanszky \& Perlman, 1969). Providing such peptides are linear, and of a size compatible with passage across the envelope (Payne $\&$ Gilvarg, $1968 b$ ), it is possible that certain of them may be accumulated by the active transport system for oligopeptides, rather than depending on simple diffusion to gain access to the organism. The fact that a bacterium can concentrate peptides with $\mathrm{N}$-methylated peptide bonds, whilst lacking peptidases able to degrade these peptides, appears of great relevance to the design of synthetic peptide antibiotics. For example, some natural peptides e.g. certain ornithyl and lysyl peptides, are extremely bactericidal towards strains devoid of peptidases for their cleavage (Payne, I968; Sussman \& Gilvarg, 1970; Gilvarg \& Levin, 1972).

The implication of these studies is important for measurement of the kinetics of bacterial peptide transport, which is made difficult using unsubstituted peptides by the presence of intensely active intracellular peptidases. Similarly, studies with mammalian systems that also appear to possess specific peptide transport systems (Matthews, 1972) are so bedevilled by problems of surface hydrolysis that, for example, debate continues about the independence of the intestinal peptide transport and peptidase action. The use of peptides with substituted peptide bonds, such as the $\mathrm{N}$-methylated peptides studied here, may help to resolve the difficulty, especially as there is some evidence that such peptides are not hydrolysed by mammalian peptidases (Fruton, Smith \& Driscoll, 1948). The results of mammalian studies may in turn be relevant to the design of synthetic peptide metabolites, especially as certain natural peptide hormones are extremely simple (Burgus \& Guillemin, 1970).

I thank my colleagues for their suggestions on the manuscript and $\mathrm{Mr} \mathrm{A} . \mathrm{R}$. Blake for technical assistance.

\section{REFERENCES}

Binkley, F., Leibach, F. \& KING, N. (1968). A new method of peptidase assay and the separation of three leucylglycinases of renal tissues. Archives of Biochemistry and Biophysics 128, 397-407.

Bodanszky, M. \& Perlman, D. (i969). Peptide antibiotics. Science, New York 163, 352-358.

Bukgus, R. \& Guillemin, R. (1970). Hypothalmic releasing factors. Annual Reviews of Biochemistry 39, $499-526$.

Davis, B. D. \& Mingioli, E. S. (I950). Mutants of Escherichia coli requiring methionine or vitamin $\mathrm{B}_{12}$. Journal of Bacteriology 6o, 1 7-28.

Fruton, J. S., Smith, V. A. \& Driscoll, P. E. (1948). On the proteolytic enzymes of animal tissues. Journal of Biological Chemistry r73, 457-469.

Gilvarg, C. \& Katchalski, E. (1965). Peptide utilization in Escherichia coli. Journal of Biological Chemistry 240, 3093-3098.

Gilvarg, C. \& Levin, Y. (1972). Response of Escherichia coli to ornithyl peptides. Journal of Biological Chemistry 247, 543-549 
Heilmann, J., Barrolier, J. \& Watzke, E. (I957). Beitrag zur Aminosäurebestimmung auf Papierchromatogrammen. Hoppe-Seyler's Zeitschrift für physiologische Chemie 309, 219-220.

Kessel, D. \& LubIN, M. (1963). On the distinction between peptidase activity and peptide transport. Biochimica et biophysica acta 71, 656-663.

LEAvitT, R. I. \& UMBaRger, H. E. (1962). Isoleucine and valine metabolism in Escherichia coli XI, valine inhibition of the growth of Escherichia coli strain K1 2. Journal of Bacteriology 83, 624-630.

Matthews, D. M. (1972). Rates of peptide uptake by small intestine. In Peptide Transport in Bacteria and Mammalian Gut. CIBA Foundation Symposium (in the press).

PAYNE, J. W. (1968). Oligopeptide transport in Escherichia coli: specificity with respect to side chain and distinction from dipeptide transport. Journal of Biological Chemistry 243, 3395-3403.

PAYNE, J. W. (I97I $a$ ). The requirement of the protonated $\alpha$-amino group for the transport of peptides in Escherichia coli. Biochemical Journal r23, 245-253.

PAYNE, J. W. (197I $b$ ). The utilization of prolyl peptides by Escherichia coli. Biochemical Journal 123, 255-260.

PAYNe, J. W. (I972a). Mechanisms of bacterial peptide transport. In Peptide Transport in Bacteria and Mammalian Gut. CIBA Foundation Symposium (in the press).

PAYNE, J. W. (1972b). The characterization of dipeptidases from Escherichia coli. Journal of General Microbiology, 7x, 267-279.

PAYNe, J. W. \& GilvarG, C. (I968a). The role of the terminal carboxyl group in peptide transport in Escherichia coli. Journal of Biological Chemistry 243, 335-340.

PAyne, J. W. \& Gilvarg, C. (I968b). Size restriction on peptide utilization in Escherichia coli. Journal of Biological Chemistry 243, 629I-6299.

Payne, J. W. \& Gilvarg, C. (197I). Peptide transport. Advances in Enzymology 35, I87-244.

Sussman, A. J. \& GilvarG, C. (1970). Peptidases in Escherichia coli $\mathrm{KI} 2$ capable of cleaving lysine homopeptides. Journal of Biological Chemistry 245, 6518-6524.

WeISMEYER, H. \& COHN, M. (1960). The characterization of the pathway of maltose utilization by Escherichia coli. Biochimica et biophysica acta 39, 4I 7-426. 